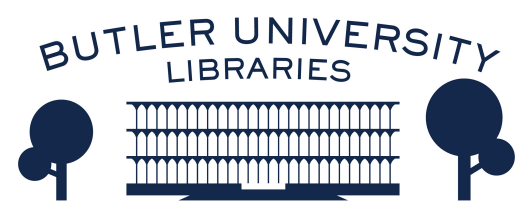

Journal of Hindu-Christian Studies

Volume 8

Article 10

January 1995

\title{
Book Review: "Theo-Monistic Mysticism: A Hindu-Christian Comparison"
}

Anantanand Rambachan

Follow this and additional works at: https://digitalcommons.butler.edu/jhcs

Part of the Religion Commons

\section{Recommended Citation}

Rambachan, Anantanand (1995) "Book Review: "Theo-Monistic Mysticism: A Hindu-Christian Comparison"," Journal of Hindu-Christian Studies: Vol. 8, Article 10.

Available at: https://doi.org/10.7825/2164-6279.1115

The Journal of Hindu-Christian Studies is a publication of the Society for Hindu-Christian Studies. The digital version is made available by Digital Commons @ Butler University. For questions about the Journal or the Society, please contact cbauman@butler.edu. For more information about Digital Commons @ Butler University, please contact digitalscholarship@butler.edu. 
recommendation is that the poems, as "scriptural manifestation", be read each day, one at a time, and assimilated into one's daily life.

Hixon's work is a personal meditation on the divine Mother, which bases itself on the skeletal work of Ramprasad Sen. This in itself is not objectionable. All beings are entitled to such meditations, and seen from this perspective, the poems are quite sensitively reworked. As a scholarly enterprise, however, the book is highly inadequate. It is riddled with generalizations and absolutist statements, too many to even mention. There is an utter lack of selfconsciousness about scholarly method. For example, even though Hixon assures us that the poems' "startling imagery and naked honesty belong to Ramprasad. My expansions have added nothing that diverges from his spirit" (p.xii), one is given no indication whatsoever as to where Ramprasad left off, and where Hixon's contemplative commentary begins. Similarly, Hixon is sometimes so indulgent to mystical language that one sometimes becomes quite lost in a quagmire of profundity. Mother of the Universe, in short, is best read as a devotional work, suited for like-minded devotees. To read it with any other aim is to be disappointed.

Arti Dand

McGill University

\section{Theo-Monistic Mysticism: A Hindu-Christian Comparison. Michael} Stoeber. New York: St Martin's Press, 1994, 135 pp.

\section{THEO-MONISTIC MYSTICISM is a} thoughtful and challenging study which seeks a middle path between two influential interpretations of mystical experiences. The constructivist interpreters, represented here by John Hick, admit that mystical experiences are different but argue that the differences are explicable by reference to the socio-religious framework which the particular mystic brings to her experience. Stoeber is critical of this school for its inability to account for the transmission of new religious knowledge and insight through mystical experience, since the information which the mystic receives is entirely dependent on the prior conceptual framework. In addition, the constructivist thesis cannot adequately account for mystic heresy or for the similarities in mystical experiences where there are no shared socioreligious factors.

The essentialist school, represented by interpreters like Evelyn Underhill, W. T. Stace and Ninian Smart, see mystical experience as the same everywhere, but subject to a variety of socio-religious interpretations. Stoeber is critical of the essentialist position for its disregard of vital differences between monistic experiences, which involve a loss of duality and exclude personal experience, and theistic experiences, which encounter the Real as dynamic and where "some sense of differentiating self-identity is maintained by the participants" (p.24). These important differences are illustrated by analysis of the writings of Meister Eckhart and Jan Van Ruusbroec.

The study of these two mystics leads Stoeber to propose a third experiential possibility which he calls theo-monistic mysticism. He calls it a theo-monistic experience "because although it involves an impersonal monistic realization, it issues in a perspective that also reflects an active, creative, and personal Real" (p.35). Theomonistic mysticism avoids the extremes of the constructivist and essentialist schools by positing that mystical experiences differ and that these differences cannot be explained 
only by socio-religious factors. The theomonistic experiences of mystics like Eckhart, Ruusbroec, Ramanuja, Aurobindo, and others can be explained only by positing a divine which is "both passive and active, non-dualistic and distinctive, impersonal and personal".

In this work, however, Stoeber does not argue only for the reality of the theomonistic type experiences. Even more importantly, he proposes, in chapters 3 and 5 , a theistic mystic typology which culminates in theo-monistic experiences but which authenticates the monistic experience and can account meaningfully for experiences of the paranormal, of nature and of the numinous. Monistic hierarchies, on the other hand, fail to fully authenticate theistic experiences and relegate them finally to the realm of the illusory.

Theo-Monistic Mysticism is a fine example of a creative scholarly work which draws deeply from the rich resources of Christianity and Hinduism while offering various possibilities for enriching dialogue. While the issue of liberation (moksa), for example, goes beyond the scope of Stoeber's work, it is central to all Hindu traditions and it needs to be raised in connection with Stoeber's characterization of monistic mysticism vis-à-vis theo-monistic mysticism. If monistic experiences are preliminary to the theo-monistic ones, are the former still liberative? What do theo-monistic experiences reveal to us about the meaning of moksa? If the divine is both personal and impersonal, non-dualistic and distinctive, we need to consider also the value of hierarchies, monistic or theo-monistic. There is little doubt that the theo-monistic category is an appropriate one for viewing a wide variety of experiences in the Hindu tradition and Stoeber's work is a catalyst for the clarification of the significance of such experiences from the Hindu point of view.

Anantanand Rambachan Saint Olaf College

\section{The Limits of Scripture: Vivekananda's Reinterpretation of the Vedas. Anantanand Rambachan. Honolulu: University of Hawaii Press, 1994, $\mathrm{xi}+170 \mathrm{pp}$.}

EVERY NOW AND then one encounters a book which brings unexpected illumination to long-standing questions. This is such a volume. Rambachan's critical analysis of Vivekananda's thought and its legacy in the Hinduism of today is as important a contribution as Wilhelm Halbfass' India and Europe. While others have highlighted Vivekananda's influence on Indian nationalism and the impact of the Ramakrishna mission, this is the first critical assessment of his thought and its influence on contemporary Hinduism - especially Advaita Vedānta of which Vivekananda claimed to be a contemporary exponent. For me this book brought answers to puzzles which had been in my mind for years: why do Hindus not show much serious scholarly interest in dialogue?; why has Hindu scholarship in this century become so flabby?; and why does Vivekananda use this extra category of rājayoga? Rambachan's critical study of Vivekananda's view of scripture (śruti), in comparison with that of Sankara, provides surprising and convincing answers to these questions.

Whereas Sankara gives priority to śruti as the only valid way to obtain knowledge of brahman and release (moksa), Vivekananda, responding to the enlightenment critique of the authority of scripture, superimposes direct personal experience (anubhava, 